\title{
Aversion toward Homosexuals among Tertiary Education Students in South Africa
}

\author{
Z. Ncanana ${ }^{1}$ \\ K.D. Ige ${ }^{2}$ \\ 1, 2Department of Sociology, University of Zululand, P/bag X1001, KwaDlangezwa, 3886, South Africa \\ ncananaz@yahoo.com'; igedavies@gmail.com²
}

\section{Doi:10.5901/mjss.2014.v5n10p569}

\section{Abstract}

This study investigated the attitudes of student at tertiary education towards homosexuals. The specific objective of the study was to investigate whether students have aversion toward or discriminate against homosexuals. Furthermore the study aimed to find out the students' perceptions of usefulness of interventions towards ameliorating the effects of discrimination towards homosexuals at the University of Zululand. The quantitative research approach was employed in this study by the use of a questionnaire in a survey of university students $(n=66)$. Data collected was analysed by using descriptive statistics, bivariate correlation and Principal Components Analysis (PCA). The findings of the study revealed that while students possess high levels of aversion toward homosexuals, the level of ostensible acts of discrimination is low. On the basis of the result, it was recommended that organising sports events and creating homosexual societies that are vibrant would encourage students to come in more contact with homosexuals in order to have more understandings and insights about homosexuality.

Keywords: Homophobia; discriination; human rights; violence; discrimination; sexuality.

\section{Introduction}

Homosexuality is an idealistic or sexual appeal of behaviour among members of the same gender. In many societies and institutions people who are homosexuals are often rejected or discriminated against or unaccepted (Arndt and Debriun, 2006). Homosexuals are also often not accepted in religious and family institutions, because it is assumed that God is not in favour of the act of homosexuality In South Africa and many other countries discrimination against homosexuals has escalated from passive rejection to brutal acts of violence. In some instances homosexuals have been publicly humiliated raped.in addition, in many African countries, new legislations are emerging that extend the frontiers of attack against the civil liberties of homosexuals. While in South Africa, homosexuals are protected by the law, traditional beliefs by many segments of the population continue to fuel homophobia and acts of hatred against this group of people. While it may be understandable why older and more conservative members of the population often hold on to traditional beliefs, the emergence of homophobia among relatively younger and supposedly more liberal people remains a puzzle. As such it is believed that there is more to find out about this issue and should be given due consideration by the students, parents and the global society. It is against this background that this research is prompted to examine the attitudes of students towards homosexuals in order to offer useful solutions towards unveiling the rationale behind such attitudes. It is therefore important to come out with new and useful solutions that will ameloorate the problems encountered by homosexuals in the communities. There have been many anti-social acts by individuals against homosexual people, therefore this should be explored and the causes determined in order to curtail incessant reoccurrences in these societies.

Former South African President Nelson Mandela signed a new constitution in 1996, making South Africa the first country in the world to integrate a sexual orientation clause in its Bill of Rights. The Constitution aimed to challenge all practices that oppose the principle of equality. This constitution has been portrayed as one of the most liberal in the world, correcting to right the wrongs of apartheid (Johnson, 1997). As a result of the privilege offered by the constitution, the long-standing invisible and silent community of South African gay men and lesbians has become more visible. Not only are gay men and lesbians in South Africa affirming themselves in sport, academics, law, and the media, their voices are also being heard in entertainment. New forms of expressions are reflected in gay and lesbian pride and parades, where participants no longer have to hide their faces behind brown paper bags, and in new-founded gay and lesbian university organization (Gevisser \& Cameron, 1995). Recently however, South African Traditional leaders appealed to lawmakers to remove a clause in the country's constitution that protects gays and lesbians against discrimination based 
on sexual orientation (City Press newspaper, 22nd May, 2012). The official body of tribal chiefs urged the parliament to debate removing the clause in Section 9 of South African Constitution that provides that "The state may not unfairly discriminate directly or indirectly against anyone on one or more grounds, including race, gender, sex, pregnancy, marital status, ethnic or social origin, colour, sexual orientation, age, disability, religion, conscience, belief, culture, language and birth." These activities and occurrences make homosexual people feel excluded and discriminated against and also isolated. This may also lead to negative influences like suicide and loss of self-esteem and at some point they may even feel vulnerable and suicidal.

Attitudes toward gays and lesbians in the US have received much attention in the press and in the campaign expression of politicians. Opinion surveys regularly include questions that attempt to gauge public sentiment regarding homosexuals, with results appearing in national publications and in candidates' stump speeches (Yang, 1997). There are some indications that homosexuality has become more accepted in the United States, as evidenced by the increasing representation of gay and lesbian characters on prime time television, and the number of elected officials who are openly homosexual (Atkinson, 2003; Ghent, 2002). A few recent developments seem to suggest that the gay movement has reached a historical high. The recent victories of equal rights for gays and lesbians have also triggered a backlash. In July 2003, $57 \%$ of Americans opposed same-sex civil unions, which was the highest since this question was first included in USA Today/CNN/Gallup polls in 2000 (McQuillan, 2003). President George W Bush also indicated his compliance to amend the Constitution to ban gay marriage. Opposing indictors of social acceptance call for a reconsideration of public attitudes in terms of trend analysis and predictors of current opinions. The sexual behaviour challenged the moral and ethical basis of the society, because it is considered as unnatural, uncultured, irreligious and immoral. It brings about a lot of social problems ranging from marital conflict, drug abuse, disease infections, clandestine same sex marriage, social ostracism, delay in marriages, loss of men appetite and many others. Young women are increasingly joined the trend because of the perceived benefits. Despite all the literature available from various parts of the world, there is still a gap in research that has to do with the attitude of students towards homosexuals on campuses.

\section{Homosexuality and Homophobia: From 'coming out' to violent reprisals}

In recent years there had been a focus towards researching about problems experienced by homosexuals in university communities. Herek (1995) found evidence of prejudice and discrimination against lesbians and gay men on campuses. Evans and D'Augelli (1996) found the campus environment to be unwelcoming and hostile towards lesbians and gay men. Wong, McCreary et al. (1999) reported that heterosexual students have negative attitudes towards lesbians and gay men. Several studies (for example; Lance, 2002) showed that verbal and behavioural hostility are directed towards lesbians and gay men (Also; Peters, 2003). At the same time, the prevailing images of lesbians and gay men were pejorative stereotypes, which fuelled homophobia. Homophobia in its extreme form is evident, even in the absence of research. Newspapers and television news reveal the nature of acts of hatred against lesbians and gay men. Research indicates that there is also an undercurrent of hostility and violence against gay men and lesbians in South Africa. Findings from studies conducted (Theunick, 2000; Reid \& Dirsuweit, 2001), point out that gay bashing and the prominence of rape is not uncommon. In addition, survey questionnaires completed by the Equality Project for the years 2001 and 2002 indicate a high level of sexual assault as an element of homophobic violence. Therefore, regardless of the fact that the South African constitution has extensive human rights protections, acknowledging the respect due to diversity in a way that the ideologies prevalent in many other countries still do not recognize; negative attitudes exist towards lesbians and gay men. Many lesbians and gay men undergo an identity transformation during their university years where they acknowledge their sexual orientation to themselves and others. Research has shown that lesbian and gay students go through a process that involves "shifting one's identity from the socially accepted heterosexual identity to the socially denigrated non-heterosexual lesbian and gay identity" (Dworkin, 2000:165).

Theorists have attempted to describe the shift in identity or the 'coming out' process. Lewis, Derlega, Griffin and Krowinski (2003) conceptualised the 'coming out' process as a series of stages proceeding from an initial awareness of being different through dissonance, grieving, and inner conflict, to gradually building a stable lesbian or gay identity complete with long-term relationships. However, research has shown that firm stage models do not provide an correct picture of identity development for many lesbians and gay men (Dube, 2000).In contrast to stage models, recent models of sexual identity suggest that identity formation is not a linear process but a fluid one, involving movement back and forth or spiralling of progression and regression (Reynolds \& Hanjorgiris, 2000). These newer models recognize that environmental constraints may prohibit public disclosure despite a successfully achieved lesbian or gay identity. Studies also indicated that the environment has a strong influence on whether, and to what extent, a person came out to others. Factors that encouraged lesbian and gay students to come out included; being around supportive people, perceiving the 
overall climate as supportive, and having lesbian and gay role models in the environment (Evans \& Broido, 1999). Over the last two decades one of the most significant findings to emerge from research is that, heterosexual men manifest more negative attitudes toward gay men and lesbian women than do heterosexual women. Welling (1994) found a higher prevalence of negative attitudes toward homosexuals in heterosexual men than women. Similarly, Herek and Capitanio (1999) found a consistent tendency for male students to express more hostile attitudes toward homosexuals than female students. Schieman (1998) found in his sample of university students that, heterosexual men reported significantly higher levels of social distance and homophobia towards gay men than towards lesbians.

\subsection{Heterosexuals' attitudes towards homosexuality}

Attitudes toward homosexuality have enhanced over the past two decades, albeit, gradually. In the USA, in 1973, homosexuality was delisted in the Diagnostic and Statistical Manual of Mental disorders. However, there was no state admitting same-sex marriage until 2001. There are many factors that relate with attitudes toward homosexuality. Kite and Whitley (2002) studied the relation between the gender of the participants and the attitudes toward homosexuality and found heterosexual men have more negative attitude toward homosexuality than heterosexual women. They also found that there was an interaction between the gender of the participants and the target; heterosexual men hold more negative views toward male homosexuality than heterosexual women. However, there were no differences between them when the target was female homosexuality. Heterosexual women made equal ratings of male homosexuality and female homosexuality, but, heterosexual men's ratings of female homosexuality were less negative than their ratings of male homosexuality. Politics can also influence the attitude toward homosexuality. Generally, acceptance of homosexuality is associated with liberalism rather than conservatism. Research into the association between Judeo-Christian religious adherence and prejudiced attitudes found church members have more negative views than non-church members. Male's fear of HIVIAIDS is significantly associated with their fear of homosexuality in a number of US studies. A questionnaire research found the participants who have the most negative views about homosexuality nearly or never have any contact with homosexuality. Considering these findings, it becomes necessary to study the factors associating with attitudes toward homosexuality.

Positive attitudes of college students toward gay, lesbian, and bisexual persons as well as toward their way of life, is necessary for effecting a more optimistic atmosphere for gays, lesbians, and bisexuals on the campuses of universities. Published research on these attitudes has historically focused on students attending large universities. These studies have commonly been of two types. The first type is the campus climate study, where a university officer completes the research in an attempt to document the extent of intolerance on campus. In the USA, some of the campuses studied in this manner include the University of California, The San Francisco State University, California State University. The second type includes research that goes beyond this to scrutinize correlates of prejudice toward gay, lesbian, and bisexual persons and research that attempts to develop intolerance scales to assess attitudes.

\subsubsection{The role of Religion}

Among the most important correlates of heterosexual attitudes toward homosexuality in previous research have been religious affiliation, religiosity, gender, and degree and type of interpersonal contact one has with gay/lesbian/bisexual (GLB) persons. A number of studies have shown strong relationships between religious characteristics and attitudes toward homosexuality. Many have reported that more conservative or fundamental beliefs are associated with stronger anti-homosexual attitudes (Cotten-Huston and Waite, 2000). Others have compared respondents by broad religious categories and have found fairly consistent patterns: Jews, those with no religious affiliation and inactive Christians have higher acceptance of gays and lesbians than Catholics; and Protestants have the most negative attitudes (Wills and Crawford, 2000). However they found no significant difference in homophobic attitudes between religiously non-affiliated persons and members of non-fundamentalist Christian groups, after other relevant variables had been controlled, among a national sample of male teenagers.

Many studies that compare denominational affiliations, including those discussed above, use a global category of 'Protestant' to compare with Catholics and Jews, even though there is strong evidence of large variation among Protestant denominations. Studies that define Protestants by specific denomination or by categories of denominational types tend to find large variation among them in attitudes toward homosexuality, with some groups approaching the more liberal end of the attitude-continuum and others showing the most hostility. For example, Fisher et al. (1994) found that Baptists, fundamentalists, and those who designated themselves simply 'Christians' displayed more antigay prejudice than others. Catholics, Episcopalians, Methodists and Presbyterians showed low to moderate levels of intolerance; Jews 
and those who indicated no religious preference showed the lowest levels. Roof and McKinney (1987: 210-214) reported that the most tolerant groups on all sexual issues were Jews, Unitarian-Universalists, and those with no religious preference. They were followed by 'Liberal Protestants', consisting of Episcopalians, Presbyterians, and United Church of Christ members. Moderate Protestant groups (Methodists, Lutherans, Northern Baptists, and Disciples of Christ) were in the middle, followed by Conservative Protestants (Southern Baptists, Churches of Christ members, Evangelicals, fundamentalists, Pentecostals, and similar groups). Catholic attitudes fell near the middle, similar on most issues to Moderate Protestants. These researchers placed Latter Day Saints (Mormons) in a separate category, but their attitudemeasures were similar to those of Conservative Protestants. No non-Christians other than Jews were included in their study. Thus, when researchers distinguish among groups of Protestants, significant differences emerge, showing the need for such classification if we are to have a meaningful comparison across denominational groups. These differences largely mirror the approaches the denominational groups have taken in their official pronouncements about sexuality.

\subsubsection{Interpersonal contact and Homophobia}

It is hypothesized that the more the contact between a person with members of stigmatized out groups, if the contact is on an equal-status basis, the lower the prejudice will be. Many studies have supported this principle and have shown that the causal effect can be in the direction of greater contact reducing prejudice. Herek and Glunt (1993) found support for this hypothesis in a study of heterosexual attitudes toward gays and lesbians. Similar findings have been reported from other studies (Wills and Crawford, 2000). These researchers argue that when heterosexuals have family members or close acquaintances who are gay or lesbian, their attitudes end to become more accepting. Both the amount of exposure to GLB individuals and the types of relationships are important: the more intimate or close the relationship, the more likely it is to affect positively a person's attitude. However, the direction of the association between contact ;and prejudice is sometimes difficult to interpret. Many heterosexuals are not aware of the sexual orientation of many of their gay friends, because of the strong stigma on homosexuality and the ease and safety with which one can remain 'in the closet', as compared to members of racial groups, for example. A gay person will obviously be more likely to "come out" to a person whose attitudes are already known to be supportive than to a highly homophobic person. Thus, the association between contact and intolerance may be two-way, or in the opposite direction from the way it is usually interpreted-that is, greater acceptance may lead to greater interpersonal contact. This should be kept in mind in interpreting these types of relationships.

\subsubsection{Gendered differences in Homophobia}

A large number of studies report that heterosexual males have more negative attitudes toward homosexuality than females (Wills and Crawford, 2000. Significantly, we have seen no studies in which women had higher antigay prejudice than men. In addition, some researchers suggest that men's attitudes are more hostile to gay men than to lesbians (Herek and Capitanio, 1999). The gender differences in homophobia may be larger among some groups than others, as Kite and Whitley (1996: 341) found the largest differences between college men and women, the least among graduate students and professionals. On the whole, however, the preponderance of the research finds that men have more negative attitudes toward homosexuality than women.

\subsubsection{Race and Ethnicity}

Racial differences in attitudes toward homosexuality have not been studied as often as gender differences, and the results tend to be less consistent. Herek and Glunt (1993) found that Black respondents had more negative attitudes than whites in a bivariate analysis, although this effect disappeared in their multivariate models. Glenn and Weaver (1979) found no significant differences between Blacks and whites in opposition to homosexual civil liberties. Herek and Capitanio (1995: 95) study of a national probability sample of Black heterosexuals concludes that "negative attitudes toward homosexuality are widespread," but probably not more than among whites. It seems likely that some of these divergent findings for African American attitudes reflect the very different age and social groups that are studied and perhaps different measurements. At this point, there is no consensus about the issue of homophobic attitudes among African Americans. The most prominent predictors of Black heterosexual attitudes toward homosexuals included their religious attendance, but not gender, education, or political ideology, all of which were significant for whites. Thus, these researchers do find evidence for some differences in the predictors of anti-gay prejudice among Blacks and whites. Kite and Whitley (1996), in an extensive meta-analysis, found a strong relationship between indices of racism and anti-gay 
attitudes, a correlation also reported by Kirkpatrick (1993). Based on this, we can assume that for white respondents, there might be a positive association between racial and sexual-orientation prejudice. We would not expect to find this for members of minority groups. Thus, we might assume that anti-gay prejudice based on a 'social-reactionary attitude' would be lower among non-whites (Kite and Whitley, 1996: 347). Thus, if different racial groups have similarly high levels of homophobia, the predictors for the different groups might be expected to be different. Other predictors of anti-gay attitudes in previous studies have included age (younger individuals' having less prejudice); education (higher education associated with lower prejudice) and gender-role attitudes. On the first two of these factors, we have controlled the variation in our study since our sample comes from a university student population with the great majority in the traditional college undergraduate age range. Although we were not able to measure gender role attitude in this study, we do not think the lack of inclusion of this measure in our analysis affects the other relationships analysed.

\section{The Present Study}

There is an increasing number of gay and lesbian students in the University of Zululand, for the past three years, each year there are new students who are rather gays or lesbians. In some instance, students who has been 'straight', neither gay nor lesbian now freely change into act of homosexuality and it is not known whether one is born with it or it is the influence of others in a form of peer influence. This indicates the need to raise the awareness of the gay and lesbian community and the broader community, regarding the violations of human rights suffered by gays and lesbians in the University. The prejudice and cruelty towards the lesbian/gay/bisexual/transgender (LGBT) population is still extremely common in society, as well as on in tertiary institutions. Past studies have suggested that males, in most cases, would have a more negative attitude toward this community of homosexuals. While the society is moving forward in upholding diversity, many youths are still maintaining that tight and baffled attitudes towards non-heterosexual lifestyles. This negative behavior leads to intolerance and coercion of the lesbian/gay/ bisexual/ transgender (LGBT) community. While there have been many studies on the attitudes of the general population toward homosexuality, there is relatively little emphasis on the attitudes of the youths and students, hence the urgent need for a study like this. Consequently, it is hypothesized as follows:

- H1: Students' aversion towards homosexuality (AVERHOM) is correlated their Perception of Discrimination against Homosexuals (PERDAHOM).

- H2: Students' aversion towards homosexuality (AVERHOM) is correlated their Perceived Intervention to protect homosexuals (PERCINTAV).

- H3: Students' Perception of Discrimination towards Homosexuals (PERDAHOM) is correlated their Perception of intervention to assist homosexuals (PERCINTAV).

\section{Research Methods}

Using the Raosoft sample size calculator ((@ http://www.raosoft.com/samplesize.html), based on the estimated population of 16, 000 University of Zululand Students, at a standard error margin of $10.93 \%$, a confidence level of $90 \%$, and a 50\% response distribution, a sample size of 66 was electronically calculated. The total sample for the study was therefore 66 respondents $(n=66)$. Respondents were selected using stratified random sampling technique from the faculties of Arts, Education, Science and Commerce and Law. Data was colleceted using a questionnaire with liket scale items. Data was analysed using Principal Components Analysis (PCA). Hypotheses were tested using bivariate correlation.

\section{Results}

\subsection{Components of AVERHOM, PERDAHOM and PERCINTAV}

In order to construct the three scales for this study, Principal Components Analysis was conducted to determine the contributions of questionnaire items. Results of Kaiser Meyer Olkin Meyer test of sample size adequacy (KMO), Bartlettlett's test of Sphericity (BTS) are presented (see appendix). Furthermore, Anti-image Covariance, Anti-image Correlations and eigen extraction are reported. 
Table 1: Descriptive Statistics of KMO and Bartlett's Test for Perceptions

\begin{tabular}{|c|c|c|c|}
\hline $\begin{array}{l}\text { Aversion towards homosexuals (AVERHOM) and Perception of } \\
\text { discrimination against homosexuals (PERDAHOM) }\end{array}$ & $\begin{array}{l}\text { Anti-image } \\
\text { Covariance }\end{array}$ & $\begin{array}{l}\text { Anti-image } \\
\text { Correlations }\end{array}$ & Extraction \\
\hline I hate Homosexuals & .330 & .885 & .589 \\
\hline Homosexuals are evil people & -.131 & -389 & .621 \\
\hline I will not want to attend same class with homosexuals & -.106 & -.356 & .680 \\
\hline Homosexuals should not be allowed in the students cafeteria & .030 & -.105 & .592 \\
\hline \begin{tabular}{|l} 
I will refuse to share same residence with a homosexual \\
\end{tabular} & -.022 & -.071 & .575 \\
\hline Homosexuals do not deserve the same rights and freedom as normal people & .025 & .091 & .679 \\
\hline Homosexuals are abnormal people & -.49 & -.128 & .480 \\
\hline People who attack homosexuals should not be arrested by the police & -.003 & -.006 & .352 \\
\hline I believe that all homosexuals are going to hell & -.100 & -.258 & .533 \\
\hline I will never associate myself with someone who is homosexual & -.038 & -.128 & .663 \\
\hline The presence of homosexuals is polluting this university campus & -.016 & -.054 & .732 \\
\hline The university should immediately expel all these homosexuals & .073 & .218 & .663 \\
\hline
\end{tabular}

Table 1 reports the resiulst of PCA for the scales; Aversion toward homosexuals (AVERHOM) and Perceptions of discriminations against homosexuals (PERDAHOM). Factor analysis outputs including correlation Matrix and Inverse of correlation Matrix to measure anti-image Covariance and anti-image Correlation of Kaiser-Meyer-Olkin sampling Adequacy and Bartlett's Test of Sphericity Chi-square Sig Test were obtained. On Aversion test (AVERHOM) on the item "I hate Homosexuals", covariance anti-image matrix showed that students' answers have strong positive sensitivity towards homosexuals on the given response with overall anti-image matrix score of (.330) which is higher than the expected (0.05), also on correlations, anti-image matrix score showed, (.885) higher than (0.05). The Aversion test on the item "Homosexuals are evil", the covariance anti-image matrix showed that students responses have mild positive sensitivity towards homosexuals with score $(-.131)$ while the correlations anti-image matrix score has (-.389) also showing mild positive responses degree. The Aversion test on "I will not like to attend the same classes with homosexuals" shows an covariance anti-image matrix score (-.106) and correlations anti-image matrix score (.105) showing higher than (0.05) and a positive sensitivity responses of the question towards homosexuals for both covariance and correlations.

Furthermore, the result sowed that the aversion test on the item "I believe that homosexuals are going to hell" shows that both the covariance anti-image matrix score $(-.100)$ and correlations anti-image matrix score $(-.258)$ have mild positive sensitivity ratings. The findings of this study on the Aversion test towards homosexuals showed highly positive sensitivity responses to the variables thus revealing that there is a strongly perceived hatred towards homosexuals by students at the University of Zululand. This finding might be due to the traditional sex role attitudes within the African societies. This finding correlates with the findings from other studies reporting positive relationship between traditional sex role attitudes and negative attitudes toward homosexuality (Herek, 1988; Kerns \& Fine, 1994). Furthermore, the findings of this study correlates with other studies by Wong et al. (1999) that reported that heterosexual students have negative attitudes towards lesbians and gay men. Lance (2002) showed that verbal and behavioral hostility are directed towards lesbians and gay men, and Peters (2003) supported these findings. Research indicates that there is also a hint of hostility and violence against gay men and lesbians in South Africa. Findings from studies conducted (Theunick, 2000; Reid \& Dirsuweit, 2001), point out that gay bashing and the prominence of rape is not uncommon.

On the Perceived Discrimination test on (PERDAHOM) 'homosexuals do not deserve the same rights and freedom as normal people the result showed a negative sensitivity responses as the covariance anti-image matrix test $(.025)$ which is less than $(0.05)$ while the correlations anti-image matrix (.091) showed mildly positive sensitivity responses. The covariance responses showed that students support the idea that homosexuals deserve the same rights and freedom like normal people. This finding correlates with the findings of Gevisser \& Cameron (1995) that the idealistic societal progressive attitude of the ruling African National Congress (ANC) shows why gay and lesbian equality bill was passed smoothly into the constitution of South Africa. In the Perceived Discrimination test on "People who attack homosexuals should not be arrested by police", the result shows highly negative sensitivity responses on both covariance anti-image matrix test of (-.003) and Correlation anti-image matrix test (0.06) which is less than expected (0.05), thus depicting that students do want anybody that attacks homosexuals to be arrested. The findings of this study correlates with the findings of Herek (2000) who reported that as "lesbians and gay men become progressively more visible in the South African society; the heterosexual public's attitudes towards them will continue to evolve." Furthermore, in the Perceived Discrimination test on "Presence of homosexuals is polluting this campus" the result showed that there is a highly 
negative response on the question as the covariance anti-image matrix test of $(-.016)$ and correlations anti-image matrix test of (-.054) showed less than expected (0.05) thus depicting that students do not support the notion that homosexuals are polluting the campuses. But other studies did not correlate with the findings of this study as Herek (1995) found evidence of prejudice and discrimination against lesbians and gay men on campuses.

\subsubsection{Perception of usefulness of interventions}

Table 2: Perception of usefulness of interventions for Homosexuals (PERCINTAV) Descriptive Statistics

\begin{tabular}{|l|c|c|c|}
\hline & Anti-image Covariance & Anti-image Correlations & Extraction \\
\hline Social activities e.g. music, sports & .456 & .812 & .783 \\
\hline Support groups & -.071 & -.183 & .823 \\
\hline Involving people who are homosexual in every event e.g. glitz & -.151 & -.446 & .876 \\
\hline Gays and lesbian month & -.028 & -.062 & .773 \\
\hline Homosexual student society & .010 & .055 & .903 \\
\hline Annual homos marathon (for support) & .027 & .087 & .876 \\
\hline
\end{tabular}

Table 2 depicts the components of Perceived Useful Interventions test for Homosexuals (PERCINTAV) using the factor analysis of correlation Matrix and Inverse of correlation Matrix to measure anti-image Covariance and anti-image Correlation of Kaiser-Meyer-Olkin sampling Adequacy and Bartlett's Test of Sphericity Chi-square Sig Test. On the Perceived Useful Interventions for Homosexual (PERCINTAV) tes on "Gays and Lesbian month" showed positive sensitivity response score of (.028) for covariance anti-image matrix which is less than (0.05) while the correlations antiimage matrix score of (.062) showed mild negative sensitivity response higher than (0.05). This shows that on covariance anti-image matrix students do not mind homosexuals having a month set aside for them. On the Perceived Useful Interventions test for Homosexual on "Homosexual student Society" has both the covariance anti-image matrix score of $(.010)$ and the correlations anti-image matrix of $(.035)$ which are less than the expected count of $(0.05)$ showing a very highly positive sensitivity response that students want homosexuals in the community to have their own students' society. The South African constitution has extensive human rights protections, acknowledging the respect due to diversity in a way that the ideologies prevalent in many other countries still do not recognize; negative attitudes exist towards lesbians and gay men (Gevisser \& Cameron, E. (1995).

Furthermore, on the Perceived useful of Interventions for Homosexuals test on "Annual homosexual marathon support has a positively sensitive response on covariance anti-image matrix score of (.027) showing that students don't mind homosexual having marathon support while the correlations anti-image matrix score of (.087) showed mildly negative response. This finding of the study correlates with the findings of Gevisser \& Cameron (1995) that found that gays and lesbians have come out to be appreciated by their excellence in sports, academics, law and media even entertainment industry. The findings of the study correlate with the findings of (Davis, 1998) in measuring the attitudes toward lesbians and gay men, finding the most significant predictors of homophobia, and documenting attitudes towards lesbian and gay male students within a South African university setting, is a critical step towards a healthy campus climate.

\subsection{Determinants of Attitudes of University students to Homosexuals}

Table 3: Correlations between AVERHOM, PERDAHOM and PERCINTAV

\begin{tabular}{|c|c|c|c|c|}
\hline & & $\begin{array}{c}\text { Aversion towards } \\
\text { Homosexual }\end{array}$ & $\begin{array}{l}\text { Perception of } \\
\text { Discrimination }\end{array}$ & $\begin{array}{c}\text { Perception of Usefulness } \\
\text { of interventions }\end{array}$ \\
\hline $\begin{array}{l}\text { Aversion towards } \\
\text { Homosexual } \\
\text { Perception of } \\
\text { Discrimination } \\
\text { Perception of Usefulness } \\
\text { of interventions }\end{array}$ & $\begin{array}{l}\text { Pearson Correlation } \\
\text { Sig. (2-tailed) } \\
\text { Pearson Correlation } \\
\text { Sig. (2-tailed) } \\
\text { Pearson Correlation } \\
\text { Sig. (2-tailed) } \\
\text { N }\end{array}$ & $\begin{array}{c}1 \\
.340^{* *} \\
.005 \\
-.291^{*} \\
.018 \\
66\end{array}$ & $\begin{array}{c}.340^{* *} \\
.005 \\
1 \\
-.199 \\
.109 \\
66\end{array}$ & $\begin{array}{c}-.291^{*} \\
.018 \\
-.199 \\
.109 \\
1 \\
\\
66\end{array}$ \\
\hline
\end{tabular}

**. Correlation is significant at the 0.01 level (2-tailed).

*. Correlation is significant at the 0.05 level (2-tailed). 
Table 3 presents the results of correlation analysis for the purpose of testing the three hypotheses formulated in this study. The result showed that students level of aversion toward homosexuals (AVERHOM) predicts their levels of perceived discrimination (PERDAHOM) toward homosexual, $r=.340, p<0.05$. The implication of this is that students who are more averse towards the idea of homosexuality are more likely to justify or engage in acts of homophobia. The result further showed that AVERHOM is negatively correlated with the perception of usefulness of interventions (PERCINTAV), $r=-.291, p<0.05$. Consequently, the more homophobic students are the less likely there are to construe interventions to prevent actions against homophobia be useful. Consequently hypotheses $\mathrm{H} 1$ and $\mathrm{H} 2$ are accepted. However, the relationship between PERDAHOM and PERCINTAV was statistically insignificant, $r=-.199, p=.109$, thus $\mathrm{H} 3$ is rejected.

The finding of this study correlates with Peters (2003) who found out that verbal and behavioral hostility are directed towards lesbians and gay men. Research indicates that there is also a hint of hostility and violence against gay men and lesbians in South Africa. Findings from studies conducted (Theunick, 2000; Reid \& Dirsuweit, 2001), point out that gay bashing and the prominence of rape is not uncommon. Furthermore, the findings correlates with the findings of Arndt and de Bruin (2006) that heterosexual students at a university in Gauteng have negative attitudes towards lesbians and gay men. In another study that correlates with this research finding, Herek (1988) and Lance (2002) showed that verbal and behavioural aggression are focussed towards lesbians and gay men.

\section{Discussion}

Students at the University of Zululand do have aversion towards homosexuals. The study confirmed the hypothesis that students at the University of Zululand do have any aversion towards homosexuals as there is no statistically significant difference on aversion towards homosexual from the Sig. (2-tailed) Pearson correlation. The finding of this study correlates with Peters (2003) who found out that verbal and behavioral hostility are directed towards lesbians and gay men. Research indicates that there is also a hint of hostility and violence against gay men and lesbians in South Africa. Findings from studies conducted (Theunick, 2000; Reid \& Dirsuweit, 2001), point out that gay bashing and the prominence of rape is not uncommon. Students at the University of Zululand do not discriminate against homosexuals. Reject the hypothesis and conclude that there is a significant difference on students' discrimination against homosexual in the study with the Sig. (.005) which is less than 0.05 levels.

The findings of the presnt study corroborates the findings of Arndt and de Bruin (2006) that heterosexual students at a university in Gauteng have negative attitudes towards lesbians and gay men. In another study that correlates with this research finding, Herek (1988) and Lance (2002) showed that verbal and behavioural aggression are focussed towards lesbians and gay men. Student's perceptions of usefulness on interventions mechanisms to curb homosexuals' apathy are not encouraging. Reject the hypothesis and conclude that there is a significant difference on students' perceptions of usefulness on interventions mechanisms to curb homosexual apathy in the study with the Sig. (.018) which is less than 0.05 levels. This finding of the study correlates with the findings of Gevisser\& Cameron (1995) that found that gays and lesbians have come out to be appreciated by their excellence in sports, academics, law and media even entertainment industry.

The findings of this study correlates with the findings of Herek (2000) who stated that as lesbians and gay men become progressively more visible in the South African society; the heterosexual public's attitudes towards them will continue to evolve." 6 discusses the Aversion of students towards homosexuals (AVERHOM) and Perceptions of discriminations against homosexuals (PERDAHOM) using the factor analysis of correlation Matrix and Inverse of correlation Matrix to measure anti-image Covariance and anti-image Correlation of Kaiser-Meyer-Olkin sampling Adequacy and Bartlett's Test of Sphericity Chi-square Sig Test. On Aversion test(AVERHOM) on "I hate Homosexuals", covariance anti-image matrix showed that students' answers have strong positive sensitivity towards homosexuals on the given response with overall anti-image matrix score of (.330) which is higher than the expected (0.05), also on correlations, anti-image matrix score has (.885) higher than (0.05).

The Aversion test on "Homosexuals are evil", the covariance anti-image matrix showed that students responses have mild positive sensitivity towards homosexuals with score (-.131) while the correlations anti-image matrix score has (.389) also showing mild positive responses degree. The Aversion test on "I will not like to attend the same classes with homosexuals" shows that the covariance anti-image matrix score (-.106) and correlations anti-image matrix score (.105) showing higher than (0.05) and a positive sensitivity responses of the question towards homosexuals for both covariance and correlations. The Aversion test on "I believe that homosexuals are going to hell" shows that both the covariance antiimage matrix score $(-.100)$ and correlations anti-image matrix score $(-.258)$ have mild positive sensitivity ratings. The findings of this study on the Aversion test towards homosexuals showed highly positive sensitivity responses to the variables and thus revealing that there is a strongly perceived hatred towards homosexuals by students at the University 
of Zululand. This finding might be due to the traditional sex role attitudes within the African societies. This finding correlates with the findings from otherstudies report that there is a positive relationship between traditional sex role attitudes and negative attitudes toward homosexuality (Herek, 1988; Kerns \& Fine, 1994). Furthermore, the findings of this study correlates with other studies by Wong et al. (1999) that reported that heterosexual students have negative attitudes towards lesbians and gay men. Lance (2002) showed that verbal and behavioral hostility are directed towards lesbians and gay men, and Peters (2003) supported these findings. Research indicates that there is also a hint of hostility and violence against gay men and lesbians in South Africa. Findings from studies conducted (Theunick, 2000; Reid \& Dirsuweit, 2001), point out that gay bashing and the prominence of rape is not uncommon.

On the Perceived Discrimination test on (PERDAHOM) homosexuals do not deserve the same rights and freedom as normal people "showed negative sensitivity responses as the covariance anti-image matrix test (.025) which is less than $(0.05)$ while the correlations anti-image matrix (.091) showed mildly positive sensitivity responses. The covariance responses show that students support the idea that homosexuals deserve the same rights and freedom like normal people. The study findings correlate with the findings of Gevisser \& Cameron, E. (1995) that the idealistic societal progressive attitude of the ruling African National Congress (ANC) shows why gay and lesbian equality bill was passed smoothly into the constitution of South Africa. In the Perceived Discrimination test on "People who attack homosexuals should not be arrested by police", shows highly negative sensitivity responses on both covariance anti-image matrix test of (-.003) and Correlation anti-image matrix test (0.06) which is less than expected (0.05), thus depicting that students do want anybody that attacks homosexuals to be arrested. The findings of this study correlates with the findings of Herek (2000) who stated that as "lesbians and gay men become progressively more visible in the South African society; the heterosexual public's attitudes towards them will continue to evolve."

In the Perceived Discrimination test on "Presence of homosexuals is polluting this campus" showed that there is a highly negative responses on the question as the covariance anti-image matrix test of (-.016) and correlations anti-image matrix test of $(-.054)$ showed less than expected $(0.05)$ thus depicting that students do not support the notion that homosexuals are polluting the campuses. But other studies did not correlate with the findings of this study as Herek (1995) found evidence of prejudice and discrimination against lesbians and gay men on campuses, Evans and D'Augelli (1996) findings. Perceived Useful Interventions test for Homosexuals (PERCINTAV) using the factor analysis of correlation Matrix and Inverse of correlation Matrix to measure anti-image Covariance and anti-image Correlation of Kaiser-Meyer-Olkin sampling Adequacy and Bartlett's Test of Sphericity Chi-square Sig Test. On the Perceived Useful Interventions test for Homosexual (PERCINTAV) on "Gays and Lesbian month" showed positive sensitivity response score of (.028) for covariance anti-image matrix which is less than (0.05) while the correlations anti-image matrix score of (.062) showed mild negative sensitivity response higher than (0.05). This shows that on covariance anti-image matrix shows that students do not mind homosexuals having a month set aside for them. Similarly, On the Perceived Useful Interventions test for Homosexual on "Homosexual student Society" has both the covariance anti-image matrix score of (.010) and the correlations anti-image matrix of (.035) which are less than the expected count of $(0.05)$ shows a very highly positive sensitivity response that students want homosexuals in the community to have their own students' society.South African constitution has extensive human rights protections, acknowledging the respect due to diversity in a way that the ideologies prevalent in many other countries still do not recognize; negative attitudes exist towards lesbians and gay men (Gevisser \& Cameron, 1995). 2000). On the Perceived useful Interventions test for Homosexuals on "Annual homosexual marathon support has a positively sensitive response on covariance anti-image matrix score of (.027) showing that students don't mind homosexual having marathon support while the correlations anti-image matrix score of (.087) showed mildly negative response from the study. This finding of the study correlates with the findings of Gevisser \& Cameron (1995) that found that gays and lesbians have come out to be appreciated by their excellence in sports, academics, law and media even entertainment industry. The findings of the study correlate with the findings of (Davis, 1998) in measuring the attitudes toward lesbians and gay men, finding the most significant predictors of homophobia, and documenting attitudes towards lesbian and gay male students within a South African university setting, is a critical step towards a healthy campus environment.

\section{Conclusion}

The findings of this study on the Aversion test towards homosexuals showed highly positive sensitivity responses to the variables and thus revealing that there is a strongly perceived hatred towards homosexuals by students at the University of Zululand. Research indicates that there is also a hint of hostility and violence against gay men and lesbians in South Africa. Findings from past studies showed that gay bashing and the prominence of rape is not uncommono, examine whether students discriminate against Homosexuals at the University of Zululand. The findings showed that the idealistic 
societal progressive attitude of the ruling African National Congress (ANC) shows why gay and lesbian equality bill was passed smoothly into the constitution of South Africa. However, some studies did not correlate with the findings of this study as Herek (1995) found evidence of prejudice and discrimination against lesbians and gay men on campuses. Evans and D'Augelli (1996) found the campus environment to be unwelcoming and hostile towards lesbians and gay men, ascertain students perceptions of usefulness of interventions towards homosexuals magnitude at the University of Zululand. findings of (Davis, 1998) in measuring the attitudes toward lesbians and gay men, finding the most significant predictors of homophobia, and documenting attitudes towards lesbian and gay male students within a South African university setting, is a critical step towards a healthy campus climate South African constitution has extensive human rights protections, acknowledging the respect due to diversity in a way that the ideologies prevalent in many other countries still do not recognize, negative attitudes exist towards lesbians and gay men (Gevisser \& Cameron, (1995). From the finding of this study that students are aware of homosexuals living among the in the campus shows that they can get to know them more so as to understand and have in sight of homosexual behaviour as well as the mental state. Hence this study shows that students are more familiar with homosexuals and therefore homosexuals in the University of Zululand are not receiving higher percentage of maltreatment like in any other societies or institution.

The Aversion test towards homosexuals showed highly positive sensitivity responses to the variables and thus revealing that there is a strongly perceived hatred towards homosexuals by students at the University of Zululand, that students do not support the notion that homosexuals are polluting the campuses, that students do want anybody that attacks homosexuals to be arrested and prosecuted and also show that students support the idea that homosexuals deserve the same rights and freedom like normal people. On perceptions of usefulness of interventions towards homosexuals at the University of Zululand, students do not mind homosexuals having a month set aside for them and lastly students want homosexuals in the community to have their own students' society and engage in marathon support, sports and entertainment so as other straight people as part of interventions. Students at the University of Zululand do have aversion towards homosexuals was tested and found out that student's perceived aversion on homosexuals in the campus. This depicted that strongly perceived hatred or negative sensitivity stance of students on homosexuals from this study even though they may not discriminate against them as revealed by the study. Students at the University of Zululand do not discriminate against homosexuals was tested and results showed that students do not discriminate against homosexuals at the University of Zululand even though they have strong aversion for them. Students perceptions of usefulness on interventions mechanisms to curb homosexuals are not encouraging was tested and outcomes showed that students do not mind homosexual having their own students' society, sports day including marathon, events and glitz to promote their own human rights and awareness that they can be treated equally like normal persons.

\section{Recommendations}

On the basis of the research results and the need to reduce negative attitudes towards homosexuals on campus, it is recommended that more programmes should be created to allow better accommodation of homosexuals to partake in extracurricular activities in order for students to have more informed insights about them. In addition, university authorities must ensure and uphold human rights and access for homosexuals to be seen as human beings and to remove any prejudice and judgmental attitude toward homosexuals on the campus.

\section{References}

Arndt, M \& Debruin, G (2006). Attitudes Toward Lesbians and Gay Men: Relations with Gender, Race and Religion among University Students. PINS, 33, 16-30.

Atkinson, C (2003). Marketers warm up to gay audience. Advertising Age, 4: 26-42.

City Press newspaper, (22 May 2012).

Davis, W M (1998) Toward civility: Assessment as a means toward improving campus climate. College Student Affairs Journal, 18, $72-$ 84.

Dube, E M (2000). The role of sexual behaviour in the identification process of gay and bisexual males. The Journal of Sex Research, 37, 123-132.

Dworkin, S H (2000). Individual therapy with lesbian, gay, and bisexual clients. In: R.M. Perez, K.A. DeBord, \& K.J. Bieschke (Eds). Handbook of counselling psychotherapy with lesbian, gay and bisexual clients. Washington, DC: American Psychological Association.

Evans, N J \& Broido, E M (1999) Coming out in college residence halls: Negotiation, meaning making, challenges, supports. Journal of College Student Development, 40, 658 -667.

Evans, N J \& D'Augelli, A R (1996) Lesbians, gay men, and bisexual people in college, in Savin-Williams, R C \& Cohen, K M (eds) 
(1996) The lives of lesbians, gays and bisexuals: Children to adults. Fort Worth: Harcourt Brace.

Gevisser, M \& Cameron, E (1995). Defiant Desire. Gay and lesbian lives in South Africa. New York: Routledge.

Ghent, B (2002). Politics: Ballot battlegrounds. The Advocate, 14: 25-27.

Griffin, G (1998) Understanding heterosexism - the subtle continuum of homophobia. Women and Language, 21, 33-40

Herek, G M (1995). Stigma and sexual orientation: Understanding prejudice against lesbians, gay men, and bisexual: Psychological Perspectives on Lesbian and gay issues. Thousand Oaks, CA: Sage.

Herek, G M (1987) Religious orientation and prejudice. Personality and Social Psychology Bulletin, 13, 34-44.

Herek, G M (ed) (1995) Stigma and sexual orientation: Understanding prejudice against lesbians, gay men, and bisexuals. Psychological Perspectives on Lesbian and gay issues. Thousand Oaks, CA: Sage.

Herek, G M (2000) The psychology of sexual prejudice. Current Directions in Psychological Science, 9, 19-22.

Herek, G M \& Capitanio, J P (1999) Sex differences in how heterosexuals think about lesbians and gay men: Evidence from survey context effects. The Journal of Sex Research, 36, 348-361.

Herek, G M \& Glunt, E K (1993). Interpersonal contact and heterosexuals attitudes towards gay men: Results from a national survey. The Journal of Sex Research, 30, 239-244.

Johnson, V E. (1997). Making words on a page become everyday life: A strategy to help gay men and lesbians achieve full equality under South Africa's constitution. Emory International Law Review, 11 (2), 583-632.

Kite M E \& Whitley, B E (1996). Sex differences in attitudes towards homosexual persons, behavior, and civil rights: A meta-analysis. Personality and Social Psychology Bulletin, 22, 336-353.

Lance, L M (2002) Heterosexism and homophobia among college students. College Student Journal, 36, 410-415.

McQuillan, L (2003). President moves to define marriage: Legislation in works to deny right to gays. USA Today, July, 31 2003, p. 1A.

Peters, J P (2003). Isolation or inclusion: Creating safe spaces for lesbian and gay youth. Families in Society, 84, 331-340.

Reynolds, A. L. \& Hanjorgiris, W.F. (2000). CoAlwood, E. (1996). Straight news: Gays, lesbians, and the news media. New York: Columbia University Press.

Reid, G \& Dirsuweit, T (2001) Understanding systematic violence: Homophobic attack in Johannesburg and its surrounds. Unpublished Dissertation. Johannesburg: Wits Institute of Social and Economic Research.

Roof, W C \& McKinney, W (1987). American mainline religion: Its changing shape and future. New Brunswick, NJ: Rutgers University Press.

Schieman, S (1998) Gender and AIDS related psychosocial processes: A study of perceived susceptibility, social distance and homophobia. AIDS Education and Prevention, 10, 264-277.

Theunick, A (2000) The traumatic impact of minority stressors on males self-identity as homosexual or bisexual. Unpublished Masters thesis. University of the Witwatersrand, Johannesburg.

Wellings, K, Field, J., Johnson, A.M. \& Wadsworth, J (1994) Sexual behaviour in Britain. Harmondsworth: Penguin.

Wills, G and Crawford, R ( 2000). Attitudes Toward Homosexuality in Shreveport-Bossier City, Louisiana. Journal of Homosexuality, 38:97-116.

Wong, F. Y, McCreary, R D, Carpenter, K M, Engle, A \& Korchynsky, R (1999) Gender-related factors influencing perceptions of homosexuality. Journal of Homosexuality, 37, 19-30.

Yang, A (1997). The polls-trends: Attitudes toward homosexuality. Public Opinion Quarterly, 61, 477-507. 